\title{
A Current Appraisal of Health and Nutrition Related Claims in Indian Children' Television Food Advertisements
}

\author{
Mekam Maheshwar (Corresponding author) \\ National Institute of Nutrition (ICMR) \\ Jamai Osmania P. O., Hyderabad, India- 500007 \\ Tel: 91-98-4895-6136 E- mail: maheswarnin@yahoo.com
}

\begin{abstract}
Vijayapushpam T.
National Institute of Nutrition (ICMR)

Jamai Osmania P. O., Hyderabad, India- 500007

Tel: 91-40-2719-7375 E- mail: pushpaviji@yahoo.com
\end{abstract}

Sylvia Fernandez Rao

National Institute of Nutrition (ICMR)

Jamai Osmania P. O., Hyderabad, India- 500007

Tel: 91-40-2719-7386 E- mail: syl_vijay@yahoo.com

Received: December 30, 2013 Accepted: February 25, 2014 Published: February 27, 2014

doi:10.5296/jsss.v1i2.5206 URL: http://dx.doi.org/10.5296/jsss.v1i2.5206

\begin{abstract}
This article reports a content analysis of health-and nutrition-related claims used in food advertisements in popular children's television channels of India. The authors analyzed 793 food ads ran for a total duration of 20,260 seconds in a span of 7 days in two television channels. Their research shows that nutrient content claims (i.e., ones that focus on a specific nutrient component such as "low in fat") are the most predominantly used, followed by
\end{abstract}


general nutrition claims, structure/ functional claims, and healthy claims. The least used category is health claims, in which the advertised food is linked to reduced risk of a disease or health problem. Researchers analysis suggests that healthy foods are not advertised nearly as much as unhealthy foods, which continue to be a major public health concern. This seems to suggest a pressing need for marketing promotions that focus on healthier food options, particularly targeting vulnerable populations such as children.

Keywords: Children, Television, Food advertisements, HNR claims 


\section{Introduction}

Obesity is evolving as a major nutritional problem in developing countries including India, affecting a substantial number of adults and resulting in an increased burden of chronic disease (WHO, 2005). The last two decades of the previous century have witnessed dramatic increase in health care costs due to obesity and related issues among children and adolescents (Wang \& Dietz, 2002). In India too, Childhood obesity showed an increasing trend (Raj et al., 2007). Obesity in children appears to increase the risk of subsequent morbidity, whether or not obesity persists into adulthood (Must et al., 1992). Outcomes related to childhood obesity include hypertension, type 2 diabetes mellitus, obstructive sleepapnoea, and orthopaedic and psychosocial problems (Barlow \& Dietz, 1998; Nanda, 2004; Li et al., 2004). Studies on urban Indian schoolchildren from selected regions report a high prevalence of obese and overweight among the children (Chhatwal et al., 2004; Marwaha et al., 2006). In addition, studies on Indian school children have also demonstrated that the prevalence of hypertension in overweight children is significantly higher than that among normal children (Mohan \& Kumar, 2004).

Increased food consumption coupled with a lack of physical activity remains a serious problem, among the many factors that cause obesity in India, particularly in urban areas. Indians spend about $25 \%$ of their income on food (CMIE 2008-2009). Affordability and greater availability of convenience foods have caused urban Indians to eat more meals outside of their homes and engage in heavy snacking. Individual dietary choices, although likely determined by a combination of personal, social, and economic factors, are also influenced by food marketing and advertising. To help consumers make more healthful food choices, Government of India notified Food Safety \& Standard Authority (FSSA) rules in 2011 to encourage food packaging and advertisements to focus less on taste and convenience, more on education and health. This FSSA rules in concordance with later Guidelines for Labeling and Claims in 2012, could result in the creation of general categories of health-and-nutrition-related (HNR) claims to be used in food advertising.

Using HNR claims in food ads has several benefits. HNR claims can convey relevant food information and health benefits to consumers that would otherwise be unknown to them (Van Trijp \& Van der Lans, 2006). With these benefits, monitoring the ways in which food advertisements use health-and-nutrition-related claims constitutes a meaningful media surveillance task for health communication researchers and professionals. The present study then seeks to examine the usage of health-and-nutrition-related claims in food advertisements through a content analysis of popular children' television channels, providing an appraisal of the ways in which health-and-nutrition-related claims are used in food ads.

In India, there are two categories of health-and-nutrition-related claims (FSS-Packaging \& Labeling Regulations, 2011) that can be used in food and dietary supplement labels and advertising: (a) health claims, which include reduction of disease risk claims and other function claims (b) nutrition claims, include nutrient content claim and nutrient comparative claim. Health claims describes relationship between a food or a constituent of that food and health. This includes the physiological role of the nutrient in growth, development and 
normal functions of the body. And/ or linking consumption of a food to the reduced risk of developing a disease or health- related condition. Nutrition claims are used to describe the level of a nutrient contained in a food (example: "source of calcium"; "high in fiber and low in fat"). This claim may also compare the nutrient levels/ energy values of two or more foods (example: "reduced"; "less than"; "fewer"; "increased"; "more than").

Television studies conducted in Australia (Hebden et al., 2011; Roberts \& Pettrigew, 2007) noted that the majority of food advertisements are against regulated healthy eating guidelines and have even exaggerated health claims to make viewers believe that natural foods can be substituted for packaged foods. A similar study by Kelly and Chapman (2007) analyzed food advertisements in popular Australian children's magazines. They found a strong skew toward unhealthy foods, sending a mixed message to children. Abbatangelo-Gray et al. (2008) found a low percentage of ads used nutrient content claims and health claims after analyzing 17.5 hours of television programming over two years. Another study looking at television programming in the United Kingdom found that nutrient content claims were used the most in advertisement, followed by function claims, comparative claims and general nutrition claims (Brennan et al., 2008). A noteworthy study conducted by Parker (2003) analyzed health-and-nutrition-related claims usage in food advertisements in three popular consumer magazines, published between 1998 and 2000 with heavy female readership observed that, nutrient content claims were the most common type of health-and-nutrition-related claims used in food advertisements. This particular finding, according to Parker, was contradictory to the wide availability of guidelines for the use of health claims (i.e., ones that link the advertised food with reducing the risk of a disease). In other words, food marketers preferred nutrient content claims to health claims in spite of increasing U.S. Food and Drug Administration support for the latter.

In India, there is limited research that specifically examines the use of health-and-nutrition-related claims in food advertisements. "Since television commercials of foods high in fat, sugar or salt greatly influence eating habits of the young and impressionable and make them vulnerable to non-communicable diseases, World Health Organization (WHO) has urged countries to reduce exposure of children to such marketing by implementing a set of international recommendations" (Vineeta \& Pandey 2011). A study by Diabetes Foundation of India (DFI) found that TV commercials have such impact on schoolchildren that they consider eating fatty foods fashionable. At least $54 \%$ of children surveyed preferred buying foods shown in commercials and 59\% said they would continue to buy such foods (Bhardwaj et al., 2008). This study concluded that, "Junk food advertisements have profound effect on children's eating habits since they are frequently displayed during prime time without legal or official regulation." Scientific reviews have also shown that a significant portion of television promotional expose children to "non-core" food products which have low nutritional value and cause child obesity.

In this context, the present study aims to provide a renewed look at the usage of health-and-nutrition-related claims in television food advertisements by examining popular children television channels. 


\section{Materials and Method}

Television Rating Points (TRP) were used to select television channels for this study. Of total 10 children television channels in India, 'Cartoon Network' and 'Disney', two most popular children channels of India were selected. 'Cartoon Network' is the first kids channel in India available on all major satellite and cable television providers. Specifically for South Asian region, this channel primarily airs animated shows in four different languages: Hindi, English, Tamil and Telugu. This is a 24-hour channel and has larger viewership among kids in India. 'Disney' is also a 24-hour television channel aimed at children and families, available on all major satellite and cable television providers. The telecast schedule of this channel consists largely of original series aimed at pre-teens and young teenagers.

Table 1. Statement showing classification of food advertisements telecasted in children's television channels from 23-29 October, 2012

\begin{tabular}{|c|c|c|c|c|c|c|c|}
\hline \multirow[t]{2}{*}{ Product } & \multicolumn{3}{|c|}{ No. of advertisements } & \multicolumn{3}{|c|}{$\begin{array}{l}\text { Duration of advertisements } \\
\text { (in seconds) }\end{array}$} & \multirow{2}{*}{$\begin{array}{l}\text { Health/ } \\
\text { Nutritional } \\
\text { Claims }\end{array}$} \\
\hline & $\begin{array}{l}\text { Cartoon } \\
\text { Network }\end{array}$ & Disney & Total & $\begin{array}{l}\text { Cartoon } \\
\text { Network }\end{array}$ & Disney & Total & \\
\hline $\begin{array}{l}\text { Biscuits/ } \\
\text { Cakes }\end{array}$ & 61 & 16 & 77 & 1220 & 430 & 1650 & $\begin{array}{l}\text { Complete health / } \\
\text { high protein }\end{array}$ \\
\hline $\begin{array}{c}\text { Chocolate/ } \\
\text { sweet } \\
\text { products }\end{array}$ & 114 & 226 & 340 & 2790 & 6530 & 9320 & More nutrients \\
\hline $\begin{array}{c}\text { Health / } \\
\text { energy drinks }\end{array}$ & 36 & 48 & 84 & 490 & 2450 & 2940 & $\begin{array}{l}\text { Makes taller \& } \\
\text { sharper }\end{array}$ \\
\hline Dairy & - & 18 & 18 & - & 680 & 680 & $\begin{array}{l}\text { Keeps you } \\
\text { healthy }\end{array}$ \\
\hline $\begin{array}{l}\text { Grain / Fruit } \\
\text { based food } \\
\text { products }\end{array}$ & 58 & - & 58 & 980 & - & 980 & $\begin{array}{c}\text { Calcium; } \\
\text { Carbohydrates }\end{array}$ \\
\hline $\begin{array}{l}\text { Atta / Noodles } \\
\text { / Pizza }\end{array}$ & 50 & 42 & 92 & 770 & 1220 & 1990 & Low calories \\
\hline Potato chips & 12 & 14 & 26 & 190 & 380 & 570 & - \\
\hline Oils / Nuts & - & 12 & 12 & - & 370 & 370 & Tasty and healthy \\
\hline Others & 74 & 12 & 86 & 1380 & 380 & 1760 & - \\
\hline Total & 405 & 388 & 793 & 7820 & 12440 & 20260 & \\
\hline
\end{tabular}

For this study, data were collected by recording programmes of the above channels during the prime time period for a week (i.e., from $23^{\text {rd }}$ to $29^{\text {th }}$ October 2012). This week happens to be 
the first term holidays for the schools in Hyderabad, India where the study was conducted. A prime time indicates highest viewership period of the television. Accordingly daily $07.00-$ $09.00 \mathrm{hrs}$ and 17.00 - $19.00 \mathrm{hrs}$ telecast of children's channels (Cartoon Network and Disney) was recorded, amounting to a total of $56 \mathrm{hrs}$ of telecast for analysis. All the recorded telecast was viewed by the principal author of this study for coding. Food advertisements appeared in the recorded version of telecast was classified into different food categories. The duration of each advertisement (in seconds) and the food group to which it belongs was also recorded in the coding sheet.

\section{Results and Discussion}

A total of 793 food advertisements were appeared during the sample period in the two children television channels viz., Cartoon Network and Disney. Total duration of these advertisements was calculated as 20,260 seconds (ref. table). These adverts are representing one or other food manufacturer and some were even endorsed by celebrity personalities. Of the total adverts, Cartoon network has telecasted 405 advertisements on different foods with a total duration of 7,820 seconds. Similarly, Disney channel telecasted a total of 388 advertisements on different eatables with a total duration of 12,440 seconds.

Almost $90 \%$ of all these advertisements have publicized their food items as either Healthy or Nutritious or both. Only $10 \%$ of food advertisements neither claimed on Health nor on Nutrition benefits, but confined only to mention as leisure-time snacking. Of the total duration of all food advertisements during the study period $60 \%$ of them have claimed exclusively Nutrition benefits and only $20 \%$ of them claimed exclusively Health benefits and $8 \%$ claimed both the benefits. Food adverts that claimed exclusively nutrition benefits are Chocolate/ Sweets, Grain/ Fruit based food and Atta/Noodles/ Pizza. Similarly, exclusively Health claim advertisements are on Health/energy drinks, Dairy products and Oils \& nuts. Advertisements on Biscuits and cakes have run claiming both health and nutrition benefits. Only advertisements on Potato chips and miscellaneous food items have not claimed any HNR benefits.

The present study analyzed health-and-nutrition-related claims in food advertisements telecasted in popular Children's television channels of India and observed that advertisements of nutrition content claims (12,290 seconds) are triple than the health claims (3,990 seconds) in terms of duration of the ads. Advertisements about chocolates and sweet products were telecasted highest number of times and duration followed by the adverts on Atta/ Noodles/ Pizza, Health/ Energy drinks, Grain-based products and Biscuits and cakes, which are mostly consumed by children. This clearly indicates that the manufacturers of these products have targeted child audience in their advertisements. All most all the adverts on health/energy drink had boosted these drinks as inevitable for the growth of children which are likely to tempt parents and children.

Food manufactures claimed consumption of chocolates and sweet products as 'more nutrients' and ran these advertisements highest number of times during the study period (Figure 1). Health \& Energy drinks are depicted as it makes children 'taller and sharper' in their studies and enacted these advertisements with child artistes. Adverts on Atta/ noodles/ 
pizza claimed low calories and depicted even as prevention to obesity. Biscuits and Cakes were focused in the advertisements as high protein products which contribute for complete health. Similarly, adverts on grains \& fruit based food products were projected as a source of calcium and carbohydrate. Advertisements on dairy products were shown as they are meant for health being.

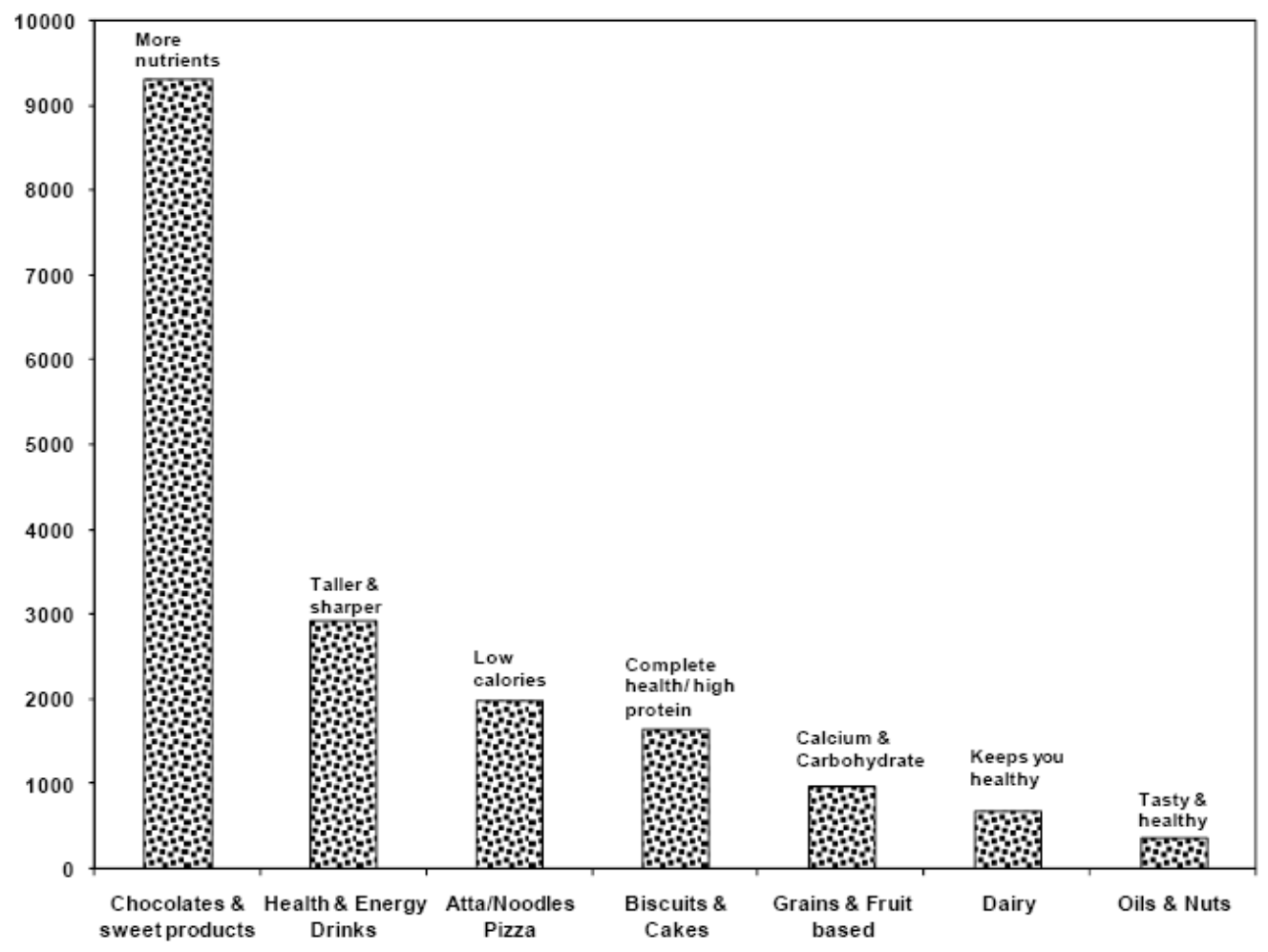

Figure 1. Duration of advertisement (in seconds) of products and their health and nutritional claims in children's television channels

Although, television channels have begun to offer more advices on healthier lifestyles, food advertisements continue to market unhealthy products (Newcastle University, 2009). Food group analysis suggests that unhealthy foods full of sweeteners, artificial flavorings, trans-fat, salt, and preservatives (e.g., fats, oils, sweets) are still among the most advertised, whereas fruits and vegetables are the least advertised categories. These findings are similar to the results of previous studies (Jones et al., 2008; Kelly \& Chapman, 2007), demonstrating the conflict between what is healthy and what is available for the general public (Cappin, 2007).

Regarding the number of health-and-nutrition-related claims used we found a significant difference in the use of general nutrition claims and structure/function claims across food groups. Among the identifiable food categories, the Atta/ noodles/ pizza was most likely to use general nutrition claims (e.g., "100\% natural whole grain wheat") and the oils \& nuts group was least likely to use these claims. The biscuit/ cakes, fruit based food products were most likely to use structure/ function claims (e.g., "Calcium for stronger bones", "high proteins build muscles for a lean body"), whereas the fats group was least likely to use these 
claims. Given the complexity of these claims and the difficulty of integrating them in advertisements, advertisers may lack the ability to effectively use health claims. However, health claims that link the product with reduced health risks or diseases may be more useful in guiding consumers to make healthy food choices, compared with nutrient content claims that simply mention a particular nutrient component.

India has been undergoing a period of change in its communications sector in the last one decade. Particularly notable are the growing importance of (often foreign) cable and satellite broadcasting, and the rise of children's television programmes. The number of television channels specifically for children grew from one in 2002 to 10 in 2012 and is still growing as broadcasters target the huge untapped market (Velloor, 2005). At the same time advertising has grown as advertisers recognize the sway of "pester power" (Business Line, 2005). A survey carried out by the NGO, Consumers International, in India in 2001, showed that $40-50 \%$ of advertising during children's programming were for food, and that more than $50 \%$ of parents cited pester power as influencing their purchasing decisions (Escalante de Cruz, 2004).

Parents play a major role in the aspect of a child's exposure to television media. Adults have the ability to think critically about the purpose and meaning of messages and how those messages can and will influence the minds of children. Family discussions should take place about commercial advertisements and the goal of the companies so children understand what they are seeing. Lifestyle habits start from a young age in direct relation to the behavior and education level of parents. This fact will have an immense impact on the continual cycle that perpetuates from generation to generation. It is also the responsibility of the advertisers and food industries to provide healthy choices as opposed to only unhealthy ones. The chance of this happening however is slim and idealistic, perfect as it may seem.

The influence of television media on food choices and eating habits of youth in America has shown to have multiple negative effects. In India, particularly in urban areas, this trend is evident as obesity in children is increasing during the past decade. The risk of unhealthy lifestyle is nothing to be ignored. Rather, it is something that needs to be addressed with high importance. The ways television media contributes to poor diet and physical inactivity include: time spent consuming media and its impact on reduced energy expenditure, eating during time spent watching television and the prevalence and impact of food advertisements. Although television media isn't all bad, there is enough evidence to conclude certain images and situations do have a negative effect on those who are exposed.

\section{Positives of Media}

Not all children's programming is "bad." In the early 2000s Shakthiman, the popular children show that promoted the idea that eating fruits and vegetables make children grow big and strong. This influence was a positive reinforcement of the food choices and eating habits parents wanted their children to practice. For adults, television can supply a resource for healthy, as opposed to harmful, media. Mainstream television channels constantly provide quick meals and menus for busy families that usually also incorporate a healthy component. On the Food Network, shows like Registered Dietitian Ellie Krieger's: Healthy Recipes, ideas 
for power breakfasts and energizing lunches as well as healthy dinners are all provided. Her advice columns are available online for those who seek more information to maintain a healthy lifestyle. These resources would not be available without the media as a component of this educational learning process.

\section{Conclusions}

The present study provides a preliminary view of how television food advertisements use health-and-nutrition-related claims. The findings hold a number of implications for health communication surrounding dietary behaviors and public policies regulating food marketing. As our study suggests, the majority of health-and-nutrition-related claims in food advertisements are nutrient content claims, rather than the more informative health claims. Food marketers appear to be reluctant to use health claims; this is could be due to television slot limitations or the required use of regulatory language. It may also be due to legal ramifications. That is, health claims need to be supported by significant scientific evidence. Otherwise, the advertiser may face charges for breaking regulations of Advertising Standards Council of India (ASCI). Establishing guidelines and /or public policies that maximize the private sectors' interest and ability to incorporate useful health-and-nutrition-related claims in food marketing seems to be much needed. Last, our analysis suggests that healthy foods are not advertised nearly as much as unhealthy foods, which continues to be a major public health concern. This seems to suggest a pressing need for marketing promotions that focus on healthier food options, particularly targeting vulnerable populations such as children.

\section{References}

Abbatangelo-Gray, J., Byrd-Bredbenner, C., \& Austin, S. B. (2008). Health and nutrient content claims in food advertisements on Hispanic and mainstream prime-time television. Journal of Nutrition Education and Behavior, 40, 348-354. http://dx.doi.org/10.1016/j.jneb.2008.01.003

Barlow, S. E., \& Dietz, W. H. (1998). Obesity evaluation and treatment: Expert Committee recommendations. The Maternal and Child Health Bureau, Health Resources and Services Administration and the Department of Health and Human Services. Pediatrics, 102, E 29.

Bhardwaj, S., Misra, A., Khurana, L., \& Gulati, S. (2008). Childhood obesity in Asian Indians: a burgeoning cause of insulin resistance, diabetes and sub-clinical inflammation. Asia Pac J Clin Nutr, 17(17), 172-175.

Brennan, R., Czarnecka, B., Dahl, S., Eagle, L., \& Mourouti, O. (2008). Regulation of nutrition and health claims in advertising. Journal of Advertising Research, 48, 57-70. http://dx.doi.org/10.2501/S0021849908080082

Business Line (India). (2005). Pester power brings more advertisers to kids channels., 18 February 2005 (accessed through Lexis-Nexis).

Chhatwal, J., Verma, M., \& Riar, S. K. (2004). Obesity among pre-adolescent and adolescents of a developing country (India). Asia Pacific Journal of Clinical Nutrition, 13, 231-5. 
CMIE. (2008-2009). Centre for Monitoring Indian Economy's Consumer Pyramids, a survey of Indian households.

Escalante de Cruz, A. (2004). The junk food generation: a multi-country survey of the influence of television advertisements on children. Kuala Lumpur, Consumers International Asia Pacific Office.

Hebden, L., King, L., Chau, J., \& Kelly, B. (2011). Food advertising on children's popular subscription television channels in Australia. Australian \& New Zealand. Journal of Public Health, 35, 127-130. http://dx.doi.org/10.1111/j.1753-6405.2011.00610.x

Jones, S. C., Andrews, K. L., Tapsell, L., Williams, P., \& Mc Vie, D. (2008). The extent and nature of "health messages" in magazine food advertising in Australia. Asian Pacific Journal of Clinical Nutrition, 17, 317-324.

Kelly, B., \& Chapman, K. (2007). Food references and marketing to children in Australian magazines: A content analysis. Health Promotion International, 22, 284-291. http://dx.doi.org/10.1093/heapro/dam026

Li, X., Li, S., Ulusoy, E., Chen, W., Srinivasan, S. R., \& Berenson, G. S. (2004). Childhood adiposity as a predictor of cardiac mass in adulthood: The Bogalusa Heart Study. Circulation, 110, 3488-92. http://dx.doi.org/10.1161/01.CIR.0000149713.48317.27

Marwaha, R. K., Tandon, N., Singh, Y., Aggarwal, R., Grewal, K., \& Mani, K. (2006). A study of growth parameters and prevalence of overweight and obesity in school children from Delhi. Indian Pediatric, 43, 943-52.

McCappin, L. (2007). Processed food is not the answer to health. Retrieved from http://www.nothingelsecompares.com/prospecting/bio-prospecting/processed-food-is-not-theanswer-to-health. php

Mohan, B., Kumar, N., Aslam, N., Rangbulla, A., Kumbkarni, S., Sood, N. K., \& Wander, G. S. (2004). Prevalence of sustained hypertension and obesity in urban and rural school going children in Ludhiana. Indian Heart Journal, 56, 310-4.

Must, A., Jacques, P. F., Dallal, G. E., Bajema, C. J., \& Dietz, W. H. (1992). Long-term morbidity and mortality of overweight adolescents: A follow-up of the Harvard Growth Study of 1922 to 1935. New England Journal of Medicine, 327, 1350-5. http://dx.doi.org/10.1056/NEJM199211053271904

Nanda, K. (2004). Non-alcoholic steatohepatitis in children. Pediatric Transplant, 8, 613-18. http://dx.doi.org/10.1111/j.1399-3046.2004.00241.x

Newcastle University. (2009). Food advertisements in your magazine: How healthy are they?

Raj, M., Sundaram, K. R., Paul, M., Deepa, A. S., \& Kumar, R. K. (2007). Obesity in Indian children: time trends and relationship with hypertension. National Medical Journal of India, 20(6), 288-93.

Roberts, M., \& Pettigrew, S. (2007). A thematic content analysis of children's food 
advertising. International Journal of Advertising, 26, 357-367.

Van Trijp, H. C. M., \& Van der Lans, I. A. (2006). Consumer perceptions of nutrition and health claims. Appetite, 48, 305-324. http://dx.doi.org/10.1016/j.appet.2006.09.011

Velloor, R. (2005). Indian TV counts on kids pester power. The Straits Times (Singapore), 4 September 2005 (accessed through Lexis-Nexis).

Vineeta, P. (2011). WHO says junk fast food TV ads targeting children. DNA daily newspaper, 24 Jan., 2011.

Wang, G., \& Dietz, W. H. (2002). Economic burden of obesity in youths aged 6 to 17 years: 1979-1999. Pediatrics, 109, E81-1. http://dx.doi.org/10.1542/peds.109.5.e81

World Health Organization. (2005). Preventing chronic diseases: A vital investment. World Global Report, Geneva: WHO.

\section{Copyright Disclaimer}

Copyright reserved by the author(s).

This article is an open-access article distributed under the terms and conditions of the Creative Commons Attribution license (http://creativecommons.org/licenses/by/3.0/). 